\title{
Decreased incidence of isolated tumor cells in lymph nodes after laparoscopic resection for colorectal cancer
}

\author{
E. S. van der Zaag • C. J. Buskens • \\ M. S. Vlug • H. M. Peters • W. H. Bouma • \\ W. A. Bemelman
}

Received: 5 October 2010/ Accepted: 12 May 2011/Published online: 24 June 2011

(C) The Author(s) 2011. This article is published with open access at Springerlink.com

\begin{abstract}
Background Laparoscopic surgery has potential for less tumor cell spread because of the no-touch technique. We assessed the effect of the surgical approach (open versus no-touch laparoscopic) on the presence of tumor cells in sentinel lymph nodes ( $\mathrm{SN}$ ) of patients with stage I and II colorectal cancer.

Methods A single-center consecutive prospective series of patients operated on for colorectal cancer was analyzed. After conventional hematoxylin and eosin (H\&E) staining, 107 patients without lymphatic metastases were included; 59 patients had open surgery, and 48 patients underwent laparoscopic resection. Patients in the laparoscopic group underwent a no-touch medial to lateral approach, whereas the conventional lateral to medial approach was applied in open surgery. A SN procedure was performed in all patients. The SNs were immunohistochemically analyzed for presence of occult tumor cells (OTC). According to the American Joint Committee on Cancer (AJCC) these tumor cells were divided into micrometastases $(0.2-2 \mathrm{~mm})$ or isolated tumor cells (ITC, $<0.2 \mathrm{~mm}$ ).

Results In ten patients micrometastases were found, equally distributed between the two groups. However, ITC

E. S. van der Zaag $(\varangle)$ - W. H. Bouma

Department of Surgery, Gelre Ziekenhuizen Apeldoorn,

Albert Schweitzerlaan 31, 7334 DZ Apeldoorn,

The Netherlands

e-mail: e.van.der.zaag@gelre.nl

H. M. Peters

Department of Pathology, Gelre Ziekenhuizen, Apeldoorn,

The Netherlands

C. J. Buskens · M. S. Vlug · W. A. Bemelman

Department of Surgery, Academic Medical Center,

Amsterdam, The Netherlands
\end{abstract}

were more often found after open surgery (18 versus 5 patients, $p=0.03$ ). Presence of OTC was related to depth of tumor invasion and tumor diameter $>3.5 \mathrm{~cm}$. Logistic regression analysis identified lymphovascular invasion as a predictor for micrometastases [odds ratio (OR) 18.4], whereas open resection was predictive for presence of ITC (OR 3.3).

Conclusions No-touch medial to lateral laparoscopic surgery results in less isolated tumor cells in lymph nodes compared with open lateral to medial surgery in patients with stage I and II colorectal cancer.

Keywords Occult tumor cells $\cdot$ SN procedure . No-touch technique · Laparoscopic surgery

During intraoperative manipulation of colorectal carcinomas, levels of circulating tumor cells (CTC) can be demonstrated in peripheral and portal blood [1]. Recently, it has been demonstrated that the cumulative percentage of CTC in peripheral and portal blood was significantly lower after laparoscopic resection in which no-touch technique was used [2]. This term refers to the principal of early lymphovascular ligation before manipulation of the tumor. In 1966, Turnbull et al. showed that early ligation increased survival rates [3]. A randomized trial suggested favorable patient-free survival and overall survival rate, however without significant difference [4]. Today, the no-touch technique is not considered the standard surgical approach in open surgery. However in laparoscopic colorectal surgery, no-touch principles can optimally be represented with the preferable medial to lateral approach where the supplying vessels are ligated before the tumor is manipulated.

If fewer CTC are detected in blood during laparoscopic surgery, it can be hypothesized that the same holds true for 
lymphatic flow with occult tumor cells (OTC) passing the lymphatic sinus. Based on the sentinel lymph node (SN) concept in which the lymphatic drainage from the primary tumor follows a specific order, we showed that OTC are preferentially found in the $\mathrm{SN}$ of patients with colorectal cancer [5].

The objective of this study is to assess the effect of the surgical approach (i.e., open lateral to medial versus laparoscopic no-touch medial to lateral approach) on levels of occult tumor cells in sentinel lymph nodes of patients with stage I and II colorectal cancer.

\section{Patients and methods}

Study population

A prospective consecutive series of patients operated on between November 2006 and June 2009 were analyzed. Only patients undergoing potentially curative resection for biopsy-proven colorectal cancer were eligible. Patients with solid organ metastases detectable by preoperative radiological staging or intraoperative visualization were excluded, as were patients with macrometastases on conventional H\&E slides. In total, 107 patients with stage I and II colorectal cancer were included (Fig. 1).

In 87 patients the choice of open or laparoscopic approach depended on the surgeon to whom the patient was referred. Twenty patients also participated in a randomized trial comparing open and laparoscopic surgery (ISRCTN: 79588422) [6]. All procedures were performed by experienced colorectal surgeons performing more than 20 procedures each year. All laparoscopic procedures were performed by one surgeon expert at laparoscopic surgery. All these resections were performed according to the notouch isolation technique (i.e., medial to lateral approach with early vessel ligation). Lateral to medial approach was performed during open resection. Patients who had early conversion, e.g., because of dense adhesions, were analyzed in the open group if the vascular trunk was not ligated before mobilization of the bowel and the lateral to medial approach was used.

The study was done in accordance with the guidelines of the local ethics committee.

Sentinel node procedure

A SN procedure was performed in all patients. Ex vivo sentinel lymph node mapping was used, as described previously in detail [7]. After resection, 0.5-2 ml patent blue (depending on the volume of the tumor) was injected below the subserosa, around the tumor, with the colonic specimen left intact. The first one to four blue lymph nodes were

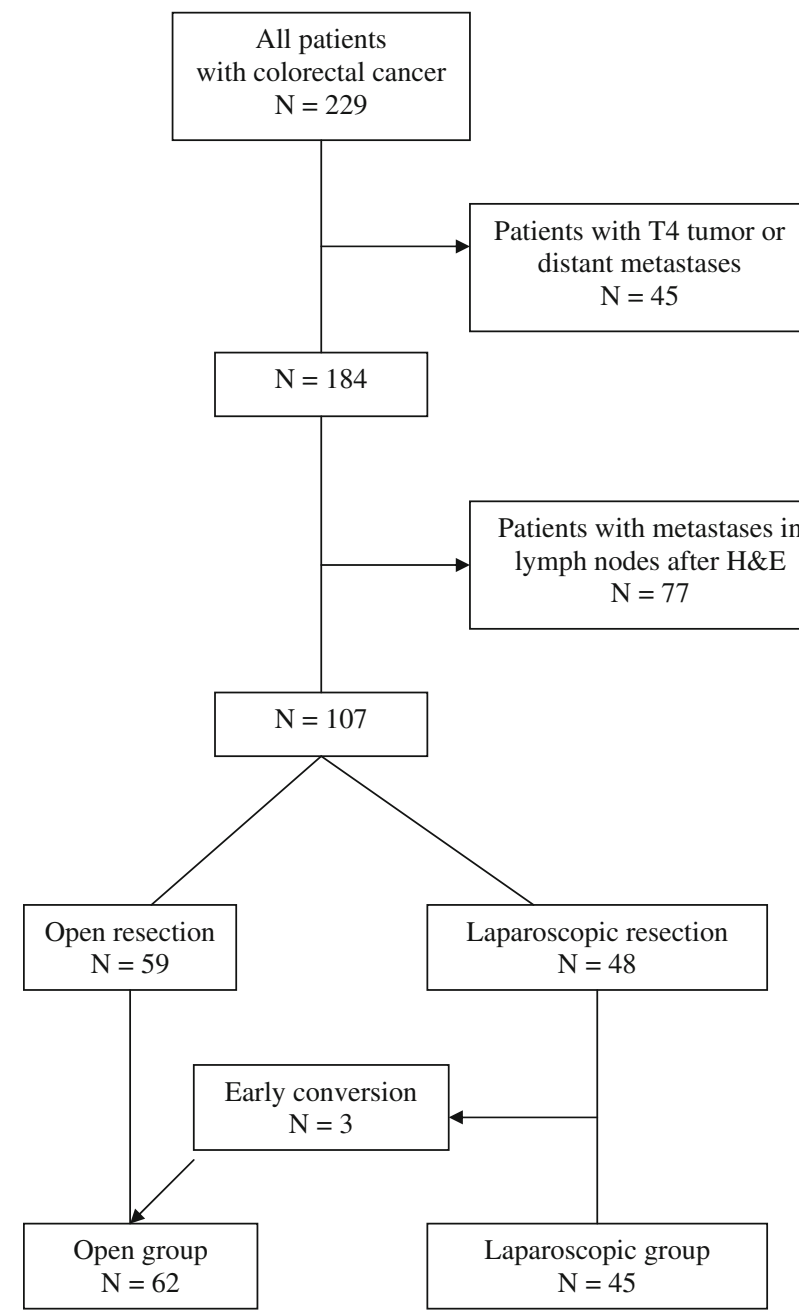

Fig. 1 Patient stream by application of inclusion criteria

identified as sentinel nodes and either dissected or marked with a suture.

Pathological examination

The surgical resection specimens were analyzed immediately at the department of pathology using a standardized protocol. Tumor stage and grading were classified according to the sixth edition of the AJCC tumor-nodemetastasis (TNM) classification [8]. All lymph nodes (SNs and non-SNs) were stained with hematoxylin and eosin and evaluated for tumor involvement.

For histologically proven N0 patients, three serial sections at $500-\mu \mathrm{m}$ intervals were immunohistochemically stained with three different monoclonal antibodies to reveal OTC. The anti-epithelial cell antibody Ber-EP4, directed against membrane glycoproteins (DAKO, The Netherlands), was combined with two anticytokeratin antibodies: CK20 with its expression limited to gastrointestinal epithelial cells (Euro Diagnostica, Arnhem, The Netherlands) and Cam5.2, 
directed against cytokeratin 7 and 8 expressed in all epithelial cells (Becton and Dickinson, Alphen aan den Rijn, The Netherlands).

Immunohistochemically detected cells with any of the three antibodies were considered as OTC only when they showed unequivocal morphological features of cancer cells. These tumor cells within lymph nodes were subdivided into two categories according to the AJCC revised guidelines: tumor cell deposits between $0.2 \mathrm{~mm}$ and $2.0 \mathrm{~mm}$ were referred to as micrometastases, and those smaller than $0.2 \mathrm{~mm}$ as isolated tumor cells (ITC) [9].

\section{Statistical analysis}

Statistical calculations were performed using the Statistical Software Package version 14.0 (SPSS Inc., Chicago, IL, USA). Categorical variables were compared using the chi-square test, while the $t$-test was used for continuous data with normal distribution. Univariate logistic regression analysis was used to identify factors predictive for detection of OTC in histologically proven NO patients. Method of resection, T-stage, differentiation grade, and tumor diameter were selected a priori as important cofactors in identification of CTC. Since the limited number of events (from a statistical point of view) meant that only a restricted number of possible predictors could be included [10], variables with multiple categories were recoded into dichotomous variables by combining categories with comparable prognosis (T-stage: I and II versus III and IV; differentiation grade: well and moderate versus poor). For tumor diameter, a cutoff of $35 \mathrm{~mm}$ was decided upon, as suggested in a study of a specifically constructed receiver-operating curve [11]. All tests were performed two sided, and $p<0.05$ was considered statistically significant. To determine the clinicopathological characteristics predictive for presence of OTC, logistic regression was performed.

\section{Results}

Characteristics of the study population

During the study period, 107 patients with stage I and II colorectal cancer were included (Table 1). Sixty-two patients were analyzed in the open group, whereas 45 patients were analyzed in the laparoscopic group (Fig. 1). There were 48 right-sided colectomies, 5 left-sided colectomies, 53 (recto)sigmoid resections, and 1 subtotal colectomy.

The patient and tumor characteristics were not different between the two patient groups, except for tumor size, which was slightly larger in the open group (Table 1).
Immunohistochemical detection of occult tumor cells

A total of 208 SNs were analyzed. Ten patients had true micrometastases of more than $0.2 \mathrm{~mm}$ in one or more $\mathrm{SNs}$ $(9.3 \%, \mathrm{pN} 1 \mathrm{mi}+)$, whereas ITC were found in 23 patients $(21.5 \%$, pNOitc+). Presence of micrometastases was equally distributed between the open and laparoscopic groups ( $n=5$ in both groups) (Table 2).

In contrast, isolated tumor cells were more frequently found in the conventional open resection group when compared with the no-touch laparoscopic group. Eighteen patients (29\%) in the open group had ITC, compared with five patients (11\%) in the laparoscopic group. This results in an absolute risk reduction for incidence of ITC of $18 \%$ and a number needed to treat of six in favor of the laparoscopic group (Table 2). One of the five patients in the laparoscopic group with ITC had a larger cluster of $0.18 \mathrm{~mm}$ with evident signs of proliferation and stromal reaction, which could therefore be considered as a micrometastasis, although we adhered to the quantitative characteristics of the AJCC. ITC were most frequently found in the sinuses of the lymph nodes, as would be expected when these cells are considered as transiently shed cells with limited lifespan.

Predictive factors for presence of occult tumor cells

A relation between presence of OTC and larger tumors (both infiltration depth and tumor diameter) was found. The occurrence of true micrometastases in the SN was strongly related to lymphovascular invasion, irrespective of surgical approach. However, this could not be demonstrated for occurrence of isolated tumor cells. Presence of these cells was only related to method of resection, with odds ratio of $3.3(1.1-9.6)$ for open lateral to medial resection (Table 3 ).

\section{Discussion}

This study demonstrates that the incidence of isolated tumor cells in lymph nodes of patients with stage I and II colorectal cancer is lower after no-touch laparoscopic resection when compared with lateral to medial open resection. These results are in line with other studies demonstrating reduced levels of CTC in peripheral and portal blood during laparoscopic resection [2, 12]. This is the first study analyzing tumor cells in lymph nodes using immunohistochemical techniques, thereby overcoming the historically controversial issues regarding reliability and reproducibility of CTC measurement in blood [13].

An advantage of analyzing OTC in lymph nodes is that histology can be preserved, discriminating between OTC and 
Table 1 Clinicopathological characteristics of the included patients

\begin{tabular}{|c|c|c|c|c|}
\hline & All patients $(n=107)$ & Open group $(n=62)$ & Laparoscopic group $(n=45)$ & $p$ Value \\
\hline Age (years) ${ }^{\mathrm{a}}$ & $70 \pm 11$ & $70 \pm 10$ & $69 \pm 12$ & 0.8 \\
\hline \multicolumn{5}{|l|}{ Gender } \\
\hline Male $^{\mathrm{b}}$ & 48 & 28 & 20 & 0.9 \\
\hline Female $^{\mathrm{b}}$ & 59 & 34 & 25 & \\
\hline Body mass index $\left(\mathrm{kg} / \mathrm{m}^{2}\right)^{\mathrm{c}}$ & $26(18-31)$ & $24(18-28)$ & $26(22-31)$ & 0.7 \\
\hline Preoperative CEA level ${ }^{\mathrm{c}}$ & $2.2(0.5-10)$ & $2.4(0.9-10)$ & $2.2(0.5-8.4)$ & 0.2 \\
\hline Tumor location $^{\mathrm{b}}$ & & & & 0.2 \\
\hline Colon & 87 & 53 & 34 & \\
\hline Rectum & 20 & 9 & 11 & \\
\hline Tumor diameter $(\mathrm{cm})^{\mathrm{a}}$ & & $5.1 \pm 2$ & $4.2 \pm 2.0$ & 0.04 \\
\hline Number of resected lymph nodes ${ }^{\mathrm{a}}$ & $15.5 \pm 7$ & $15.5 \pm 7$ & $15.6 \pm 7$ & 1.0 \\
\hline Number of identified $\mathrm{SN}^{\mathrm{a}}$ & $2.0 \pm 2$ & $1.9 \pm 2.1$ & $2.1 \pm 2.4$ & 0.7 \\
\hline Depth of invasion $^{\mathrm{b}}$ & & & & 0.7 \\
\hline pT1 & 8 & 3 & 5 & \\
\hline pT2 & 29 & 17 & 12 & \\
\hline pT3 & 68 & 41 & 27 & \\
\hline pT4 & 2 & 1 & 1 & \\
\hline Differentiation grade $^{\mathrm{b}}$ & & & & 0.2 \\
\hline Well & 9 & 5 & 4 & \\
\hline Moderate & 80 & 43 & 37 & \\
\hline Poor & 18 & 14 & 4 & \\
\hline Lymphovascular invasion $^{\mathrm{b}}$ & & & & 0.1 \\
\hline Absent & 97 & 54 & 43 & \\
\hline Present & 10 & 8 & 2 & \\
\hline
\end{tabular}

a Mean (SD)

b Absolute numbers

c Median (min.-max.)

Table 2 Presence of occult tumor cells in SN in patients with colorectal cancer: comparison between open and laparoscopic resection

\begin{tabular}{lllll}
\hline & All patients $(n=107)$ & Open group $(n=62)$ & Laparoscopic group $(n=45)$ & $p$ Value Difference $(\%)$ \\
\hline Occult tumor cells & 33 & 23 & 10 & 0.6 \\
Micrometastases & 10 & 5 & 5 & $-3 \%(-15$ to $8 \%)$ \\
$0.2-2.0 \mathrm{~mm}$ & & $8 \%$ & $11 \%$ & 0.03 \\
Isolated tumor cells & 23 & 18 & 5 & $18 \%(3-33 \%)$ \\
$<0.2 \mathrm{~mm}$ & & $29 \%$ & $11 \%$ & $18 \%$ \\
\hline
\end{tabular}

falsely positive stained cells. Most studies sampling peripheral or portal blood for CTC during surgery use reverse-transcriptase polymerase chain reaction (RT-PCR) or quantitative real-time RT-PCR. However, histological confirmation is lost in these techniques, which harbors the danger of identifying shed debris or hematopoietic cells as tumor cells.

The clinical relevance of our finding is hard to assess. Although the prognostic role of OTC seems to be established in metastasized breast, colon, and prostate cancer patients [14-16], the clinical relevance of peroperatively detected cells is still debated. So far, these cells are generally considered to be transiently shed cells without prognostic significance. The metastatic process is extremely inefficient, involving survival in circulation or lymphatics, arresting at a distant target organ, extravasation into surrounding tissue, and survival in the foreign microenvironment, followed by proliferation and induction of angiogenesis while evading apoptotic death or immunological response [17]. Tumors can shed millions of cells into the bloodstream daily, but it has been demonstrated that only a small percentage of tumor cells $(0.05 \%)$ can survive and initiate a metastatic focus [17]. 
Table 3 Logistic regression analyses of predictors for presence of occult tumor cells, micrometastases $(0.2-2.0 \mathrm{~mm})$, and isolated tumor cells $(<0.2 \mathrm{~mm})$ in histologically N0 patients with colorectal cancer

\begin{tabular}{|c|c|c|c|c|c|}
\hline \multirow[t]{2}{*}{ Variable } & & \multicolumn{2}{|c|}{ Occult tumor cells } & \multicolumn{2}{|l|}{ Isolated tumor cells } \\
\hline & & $\mathrm{OR}^{\mathrm{a}}\left(\mathrm{CI}^{\mathrm{b}}\right)$ & $p$ Value & $\mathrm{OR}^{\mathrm{a}}\left(\mathrm{CI}^{\mathrm{b}}\right)$ & $p$ Value \\
\hline Method of resection & Open versus laparoscopic & $0.5(0.20-1.16)$ & 0.1 & $3.3(1.11-9.63)$ & 0.03 \\
\hline Depth of invasion & $\mathrm{pT} 3 / 4$ versus $\mathrm{pT} 1 / 2$ & $2.5(0.99-6.6)$ & 0.06 & $2.2(0.75-6.6)$ & 0.2 \\
\hline Differentiation grade & Poor versus well and moderate & $2.1(0.75-5.78)$ & 0.2 & $2.1(0.70-6.45)$ & 0.2 \\
\hline \multirow[t]{2}{*}{ Tumor diameter } & $>3.5 \mathrm{~cm}$ versus $<3.5 \mathrm{~cm}$ & $2.7(1.05-7.08)$ & 0.04 & $1.7(0.61-4.86)$ & 0.3 \\
\hline & & \multicolumn{2}{|l|}{ Micrometastases } & \multicolumn{2}{|c|}{ Isolated tumor cells } \\
\hline Lymphovascular invasion & Present versus absent & $18.4(4.0-85.1)$ & $<0.001$ & $0.38(0.05-3.16)$ & 0.4 \\
\hline
\end{tabular}

In contrast, data on patients with breast cancer show that OTC in sentinel lymph nodes are related to reduced 5-year disease-free survival [18]. Cultured single cells from rib marrow of patients with esophagogastric cancer were viable when inoculated subcutaneously in athymic nude mice [19]. In addition, in patients with colon cancer, improved 5-year survival rates were reported combined with reduced frequency of cancer cells in portal blood using the open notouch isolation technique [3]. The only randomized trial on no-touch technique in patients with colon cancer did not show a significant increase in disease-free survival, but data demonstrated better results in all analyses for the notouch patient group (time to recurrence, incidence of liver metastases, and disease-free survival) [4].

So far, several randomized trials comparing laparoscopic with open surgery with long-term follow-up did not show survival differences [20, 21]. This would be in line with our hypothesis that the decreased number of detected ITC is merely a mechanical process depending on the surgical approach, rather than being viewed as a prognostic factor. Better disease-free survival was demonstrated in one early trial comparing laparoscopic with open resection, but this improvement was only seen in stage III patients, and therefore these results cannot be compared with our findings in histologically N0 patients [22].

Previously, it has been suggested that the decreased detection rate of CTC could be attributed to early ligation of the lymphovascular trunk (medial to lateral approach) [2]. We have demonstrated in a previous study that OTC are preferentially found in peritumoral SNs [5]. Since lymphatic drainage to peritumoral lymph nodes is not disturbed by early ligation, it is unlikely that solely a medial to lateral approach would result in decreased numbers of ITC. Therefore, our results suggest that predominantly the no-touch technique of the laparoscopic approach explains the lower incidence of ITC when compared with conventional open resection. Even without demonstrated prognostic relevance, this would make laparoscopic no-touch resection the treatment of choice for patients with stage I and II colorectal cancer. The development of all metastases will start with a single cell, and so far there are no techniques available to predict the possible survival of ITC. Although most cells will not survive circulation and immunological responses, activation of blood coagulation and relative immune suppression due to surgical stress might enhance the metastatic potential of these intraoperatively spilled cells [23, 24].

A major drawback of our study is the nonrandomized comparison. However, the decrease in ITC is not likely to be attributed to patient selection since patient and tumor characteristics, carcinoembryonic antigen (CEA) levels, and number of resected lymph nodes were comparable in the two treatment groups. There was a difference in tumor diameter, with smaller tumors in the laparoscopic group. However, regression analysis showed no relation between presence of ITC and tumor diameter. The only parameter predictive for presence of ITC was method of resection, with OR of 3.3 for open lateral to medial surgery.

\section{Conclusions}

Laparoscopic no-touch surgery results in fewer isolated tumor cells in lymph nodes compared with open lateral to medial surgery in patients with stage I and II colorectal cancer. Although prospective survival analyses in these patients with ITC and randomized trials should be awaited, every attempt should be made to prevent worsening of the prognosis of patients during surgery. In that respect, laparoscopic resection with the no-touch technique may have benefits over open surgery in patients with stage I and II colorectal cancer. 
Disclosures Authors van der Zaag, Buskens, Vlug, Peters, Bouma, and Bemelman have no conflicts of interest or financial ties to disclose.

Open Access This article is distributed under the terms of the Creative Commons Attribution Noncommercial License which permits any noncommercial use, distribution, and reproduction in any medium, provided the original author(s) and source are credited.

\section{References}

1. Yamaguchi K, Takagi Y, Aoki S, Futamura M, Saji S (2000) Significant detection of circulating cancer cells in the blood by reverse transcriptase-polymerase chain reaction during colorectal cancer resection. Ann Surg 232:58-65

2. Wind J, Tuynman JB, Tibbe AG, Swennenhuis JF, Richel DJ, Van Berge Henegouwen MI, Bemelman WA (2009) Circulating tumour cells during laparoscopic and open surgery for primary colonic cancer in portal and peripheral blood. Eur J Surg Oncol 35:942-950

3. Turnbull RB, Kenneth K, Watson FR, Spratt J (1967) Cancer of the colon: the influence of the no-touch isolation technic on survival rates. Ann Surg 166:420-427

4. Wiggers T, Jeekel J, Arends JW, Brinkhorst AP, Kluck HM, Luyk CI, Munting JD, Povel JA, Rutten AP, Volovics A, Greep JM (1988) No-touch isolation technique in colon cancer: a controlled prospective trial. Br J Surg 75:409-415

5. Van der Zaag ES, Kooij N, Peters HM, van de Vijver M, Bemelman WA, Buskens CJ (2010) Diagnosing occult tumour cells and their predictive value in sentinel nodes of histologically negative patients with colorectal cancer. Eur J Surg Oncol 36:350-357

6. Wind J, Hofland J, Preckel B, Hollmann MW, Bossuyt PM, Gouma DJ, van Berge Henegouwen MI, Fuhring JW, Dejong CH, van Dam RM, Cuesta MA, Noordhuis A, de Jong D, van Zalingen E, Engel AF, Goei TH, de Stoppelaar IE, van Tets WF, van Wagensveld BA, Swart A, van den Elsen MJ, Gerhards MF, de Wit LT, Siepel MA, van Geloven AA, Juttmann JW, Clevers W, Bemelman WA (2006) Perioperative strategy in colonic surgery LAparoscopy and/or FAst track multimodal management versus standard care (LAFA trial). BMC Surg 6:16

7. Van der Zaag ES, Buskens CJ, Kooij N, Akol H, Peters HM, Bouma WH, Bemelman WA (2009) Improving staging accuracy in colon and rectal cancer by sentinel lymph node mapping: a comparative study. Eur J Surg Oncol 35:1065-1070

8. International Union Against Cancer (UICC) (2002) TNM classification of malignant tumours, 6th edn. Wiley-Liss, New York

9. Singletary SE, Greene FL, Sobin LH (2003) Classification of isolated tumor cells: clarification of the 6th edition of the American Joint Committee on Cancer Staging manual. Cancer 98:2740-2741

10. Harrell FE Jr, Lee KL, Mark DB (1996) Multivariable prognostic models: issues in developing models, evaluating assumptions and adequacy, and measuring and reducing errors. Stat Med $15: 361-387$
11. Cahill RA, Bembenek A, Sirop S, Waterhouse DF, Schneider W, Leroy J, Wiese D, Beutler T, Bilchik A, Saha S, Schlag PM (2009) Sentinel node biopsy for the individualization of surgical strategy for cure of early-stage colon cancer. Ann Surg Oncol 16:2170-2180

12. Bessa X, Castells A, Lacy AM, Elizalde JI, Delgado S, Boix L, Piñol V, Pellisé M, García-Valdecasas JC, Piqué JM (2001) Laparoscopic-assisted vs. open colectomy for colorectal cancer: influence on neoplastic cell mobilization. J Gastrointest Surg 5:66-73

13. Ring AE, Zabaglo L, Ormerod MG, Smith IE, Dowsett M (2005) Detection of circulating epithelial cells in the blood of patients with breast cancer: comparison of three techniques. Br J Cancer 92:906-912

14. Cristofanilli M, Budd GT, Ellis MJ, Stopeck A, Matera J, Miller MC, Reuben JM, Doyle GV, Allard WJ, Terstappen LW, Hayes DF (2004) Circulating tumour cells, disease progression, and survival in metastatic breast cancer. N Engl J Med 351:781-791

15. Cohen SJ, Punt CJ, Iannotti N, Saidman BH, Sabbath KD, Gabrail NY, Picus J, Morse MA, Mitchell E, Miller MC, Doyle GV, Tissing H, Terstappen LW, Meropol NJ (2009) Prognostic significance of circulating tumour cells in patients with metastatic colorectal cancer. Ann Oncol 20:1223-1229

16. Moreno JG, Miller MC, Gross S, Allard WJ, Gomella LG, Terstappen LW (2005) Circulating tumour cells predict survival in patients with metastatic prostate cancer. Urology 65:713-718

17. Hunter KW (2004) Host genetics and tumour metastasis. Br J Cancer 90:752-755

18. de Boer M, van Deurzen CH, van Dijck JA, Borm GF, van Diest PJ, Adang EM, Nortier JW, Rutgers EJ, Seynaeve C, MenkePluymers MB, Bult P, Tjan-Heijnen VC (2009) Micrometastases or isolated tumour cells and the outcome of breast cancer. N Engl J Med 361:653-663

19. O'sullivan GC, Sheehan D, Clarke A, Stuart R, Kelly J, Kiely MD, Walsh T, Collins JK, Shanahan F (1999) Micrometastases in esophagogastric cancer: high detection rate in resected rib segments. Gastroenterology 116:543-548

20. Buunen M, Veldkamp R, Hop WC, Kuhry E, Jeekel J, Haglind E, Påhlman L, Cuesta MA, Msika S, Morino M, Lacy A, Bonjer HJ (2009) Survival after laparoscopic surgery versus open surgery for colon cancer: long-term outcome of a randomised clinical trial. Lancet Oncol 10(1):44-52

21. Jayne DG, Thorpe HC, Copeland J, Quirke P, Brown JM, Guillou PJ (2010) Five-year follow-up of the Medical Research Council CLASICC trial of laparoscopically assisted versus open surgery for colorectal cancer. Br J Surg 97(11):1638-1645

22. Lacy AM, García-Valdecasas JC, Delgado S, Castells A, Taurá P, Piqué JM, Visa J (2002) Laparoscopy-assisted colectomy versus open colectomy for treatment of non-metastatic colon cancer: a randomised trial. Lancet 359:2224-2229

23. Weitz J, Kienle P, Lacroix J, Willeke F, Benner A, Lehnert T, Herfarth C, von Knebel Doeberitz M (1998) Dissemination of tumour cells in patients undergoing surgery for colorectal cancer. Clin Cancer Res 4:343-348

24. Lundy J (1980) Anesthesia and surgery: a double-edge sword for the cancer patient. J Surg Oncol 14:61-65 